\title{
FESTA DA CARIDADE: \\ A REPRESENTAÇÃO DO NEGRO NAS COMEMORAÇÕES DO ABOLICIONISMO BELENENSE (1881-1888)
}

\author{
Carlos Denizar Machado ${ }^{1}$
}

\begin{abstract}
RESUMO
$\mathrm{O}$ artigo analisa a representação dos negros no contexto das festas do abolicionismo belenense. O trabalho discute as festas do abolicionismo enquanto discurso de caridade em torno da questão liberdade na década da abolição e a representação do negro enquanto "bom cativo", trabalhador idealizado pelas elites senhoriais. As festas eram comemoradas enquanto um ritual de "batismo da liberdade" e momento de ideal de relacionar a liberdade enquanto ação festiva de caráter benevolente, momento de harmonia e confraternização.
\end{abstract}

Palavras-chave: Caridade. Liberdade. Festas. Negro.

\begin{abstract}
The article analyzes the representation of Black people in the context of the celebrations of the abolicionism in Belém. The text discusses the parties of abolitionism as a discourse of charity around the conception of freedom in the decade of abolition and the representation of the Negro as "good captive", a worker idealized by the slaver society. The feasts were celebrated as a ritual of "baptism of freedom" and an ideal moment of relating freedom as a festive action of benevolent character, moment of harmony and fraternization.
\end{abstract}

Keywords: Charity: Freedom. Parties. Black people.

\section{INTRODUÇÃO}

Objetivo do trabalho é analisar esses festejos enquanto discurso de caridade em torno da concepção de liberdade na década da abolição e a representação do negro enquanto "bom cativo", trabalhador idealizado nos anos finais da escravidão.

O presente artigo $^{2}$ debate como foram idealizadas algumas representações do negro no processo de liberdade na capital da província do Pará. Apresento a reflexão em torno de dois

\footnotetext{
${ }^{1}$ Discente do Programa de Pós-graduação em História Social da Amazônia (PPPHIS-UFPA) em nível de mestrado e integrante do Grupo de Estudos e Pesquisas em Escravidão e Abolicionismo na Amazônia (GEPEAM). Atua na área de escravidão e abolicionismo na Amazônia em pesquisa em nível de mestrado acadêmico.

${ }^{2}$ As reflexões desse artigo fazem parte da pesquisa sobre os festejos do abolicionismo em Belém, cuja temática integra pesquisa em nível de mestrado acadêmico do Programa de Pós-Graduação em História Social da Amazônia (PPHIST) na linha de pesquisa "Etnicidade e Territorialidades- Usos e representações".
} 
eixos: O caráter harmônico e caridoso das libertações em meios a festejos e a representação dos libertados (negro) nas comemorações do abolicionismo.

Antes de analisar a questão, porém, devemos ter noção que a década de oitenta do século XIX foi marcada pela efervescência social das festas em comemoração pela libertação de escravizados. Bezerra Neto (2006) destaca que ocorreu a construção do sentido de uma memória histórica do abolicionismo paraense, apontando que eram realizados festejos relembrando algumas efemérides patrióticas constituídas para dar substância ao movimento. Festas organizadas por sujeitos que associavam às disputas da independência, requerendo status de "herdeiros" da luta pela liberdade.

Por outro lado, Machado (2010) demonstra que a década de 1880 foi arena de embate entre diversos sujeitos que buscavam estabelecer uma memória coletiva, na qual os profissionais liberais, os clubes abolicionistas/emancipacionistas e povo em geral engrossavam os meetings e disputavam a questão do processo de libertação. A autora aponta uma "onda avassaladora" no qual diferentes sujeitos estabeleceram ações envolvendo o “coração e a mente dos habitantes da cidade, assim foi, por muitos, descrito o movimento abolicionista, identificado como a conjunção de lutas parlamentares, atividades forenses, campanha jornalística e movimento popular"4.

As festas do abolicionismo marcaram uma teia de relações sociais. O caráter de subscrição, ou seja, participação de diversos segmentos sociais que organizavam festejos em que eram caracterizados pelo caráter caridoso e filantrópico.

Articulavam diversas ações públicas tais como espetáculos teatrais, bazares de caridade, quermesses redentoras, esmolações no comércio para completar ou mesmo pagar indenizações ou "doações” de cartas das alforrias. Além disso, ocorriam festas particulares (batizado, casamentos, aniversários, atos memoriais,) ou mesmo soirées que apresentavam o mesmo propósito. Essa teia de festejos era marcada pela heterogeneidade, bem como caráter espalhafatoso das cerimônias, em muitos casos, divulgada na imprensa como grande "festa" conforme identifica Vicente Salles. ${ }^{5}$

\footnotetext{
${ }^{3}$ NETO (2006, pp. 341-382).

${ }^{4}$ MACHADO (2010, p. 150).

${ }^{5}$ SALLES (2005, p. 357).
} 


\section{METODOLOGIA}

A metodologia do trabalho baseia-se na pesquisa sobre a escravidão e o abolicionismo na Amazônia na perspectiva da história social, a partir da análise bibliográfica de autores referência para o Estudo Abolicionismo na Amazônia e no Brasil, tais como José Maia Bezerra Neto, Vicente Salles, Angela Alonso e Maria Helena Machado. Acrescenta-se também análise crítica e cotejo das fontes dos periódicos de época (jornais circulantes na capital paraense- Diário de Belém, Diário de Notícias, O Liberal do Pará e A Província do Pará) na visão que estes periódicos eram meios de divulgação dos festejos e apropriados para demonstrar empatia política e social no qual as festas eram comemoradas enquanto um ritual de "batismo da liberdade" e momento de ideal de relacionar a liberdade enquanto ação de festiva de caráter benevolente, momento de harmonia e confraternização.

\section{RESULTADOS}

Partes das reflexões dessa pesquisa resultaram na escrita do primeiro e segundo capítulos de qualificação apresentada à banca examinadora do Programa de pós-graduação em História Social da Amazônia (PPHIST-UFPA), em setembro de 2018, bem como a constituição do presente artigo. Como resultado parcial obtido na pesquisa, a compreensão do sentido dos festejos e do abolicionismo, ou seja, caracterizada como festas de harmonia social, evidenciando o altruísmo dos senhores e a projeção de suas visões de mundo para os libertados, numa disputa pela memoria social da liberdade em Belém.

\section{FESTA DE LIBERDADE: AÇÃO FRATERNA, DE CARIDADE?}

A primeira questão considerada é que os festejos do abolicionismo foram organizados com a finalidade de tecer um ideal de liberdade. Em geral, essas comemorações eram pautadas por ideais de confraternização, congraçamento e altruísmo.

Conforme identifica Magda Pereira Costa, ações de caridade pública ${ }^{6}$ de diferentes sujeitos, tais como artistas, estudantes, feirantes, políticos que organizavam clubes e associações emancipacionista ou abolicionista. Essas comemorações eram programadas como "batismo da Liberdade" e espelhavam que o processo de libertação dos escravos no Pará e, consequentemente, as festas do abolicionismo, buscavam redimir a província da mancha

\footnotetext{
${ }^{6}$ Idem.
} 
escravista, em torno de um ideal de congraçamento, pautando a luta abolicionista como missão "civilizadora e luta patriótica".

Nessa perspectiva, que foram organizados bazares de caridade com esmolações de objetos e leilões de donativos para arrecadar fundos e comprar alforrias. Apresentava-se questão da liberdade do cativeiro como "missão toda de amor e caridade, do qual constituem seu fito principal a de abolir a escravatura nesta província"7.

Outra questão é que o contexto da década de oitenta do XIX a escravidão foi compreendida como um "cancro social" 8 ou "anomalia"9 e ganhou enredo uma de retórica de mudança, progresso por parte daqueles que defendiam a necessidade de aboli-la. Como afirma Bezerra Neto que "em seus embates pela construção de um mundo civilizado sem escravidão traduziam suas próprias leituras de suas práticas emancipadoras e abolicionistas como movimento de natureza patriótica, de regeneração social e civilizacional."10 De outro modo, Ângela Alonso identifica que o movimento do abolicionismo criou a "retórica de uma redenção: ao extinguir a relação senhor-escravo, a abolição resgataria a ambos."

Assim, em 1882, foi organizada ação capitaneada pela Associação Philantrópica de Emancipação de Escravos ${ }^{12}$ que por "diversos meios se há lançado mão entre nós, do assumpto que nos ocupamos, o Bazar da Caridade está demonstrando altamente que nunca é em vão o apelo em nome da liberdade." ${ }^{13}$ Esse bazar teve duração aproximadamente de três meses e movimentou diversos segmentos sociais em torno da questão da emancipação dos escravos (Figura1).

\footnotetext{
${ }^{7}$ O Liberal do Pará (9 de abril de 1882, p.1).

${ }^{8}$ Diário de Notícias. Libertação de Benevides (30 de março de 1884, p.1).

${ }^{9}$ Diário de Notícias. As conferencias (13 de maio de 1884, p.2).

10 BEZERRA NETO, 2009, p. 11.

${ }^{11}$ ALONSO, 2015, p. 144.

12 De acordo com Bezerra Neto (2009, p. 329), essa sociedade emancipadora teve sua festa entrelaçada com as comemorações do dia 28 de setembro de 1871 (Lei do Ventre Livre) ocorrendo à posse de seus novos diretores.

${ }^{13}$ A Província do Pará (22 de julho de 1882, p. 3).
} 
Figura 1: Bazar da Caridade. ${ }^{14}$

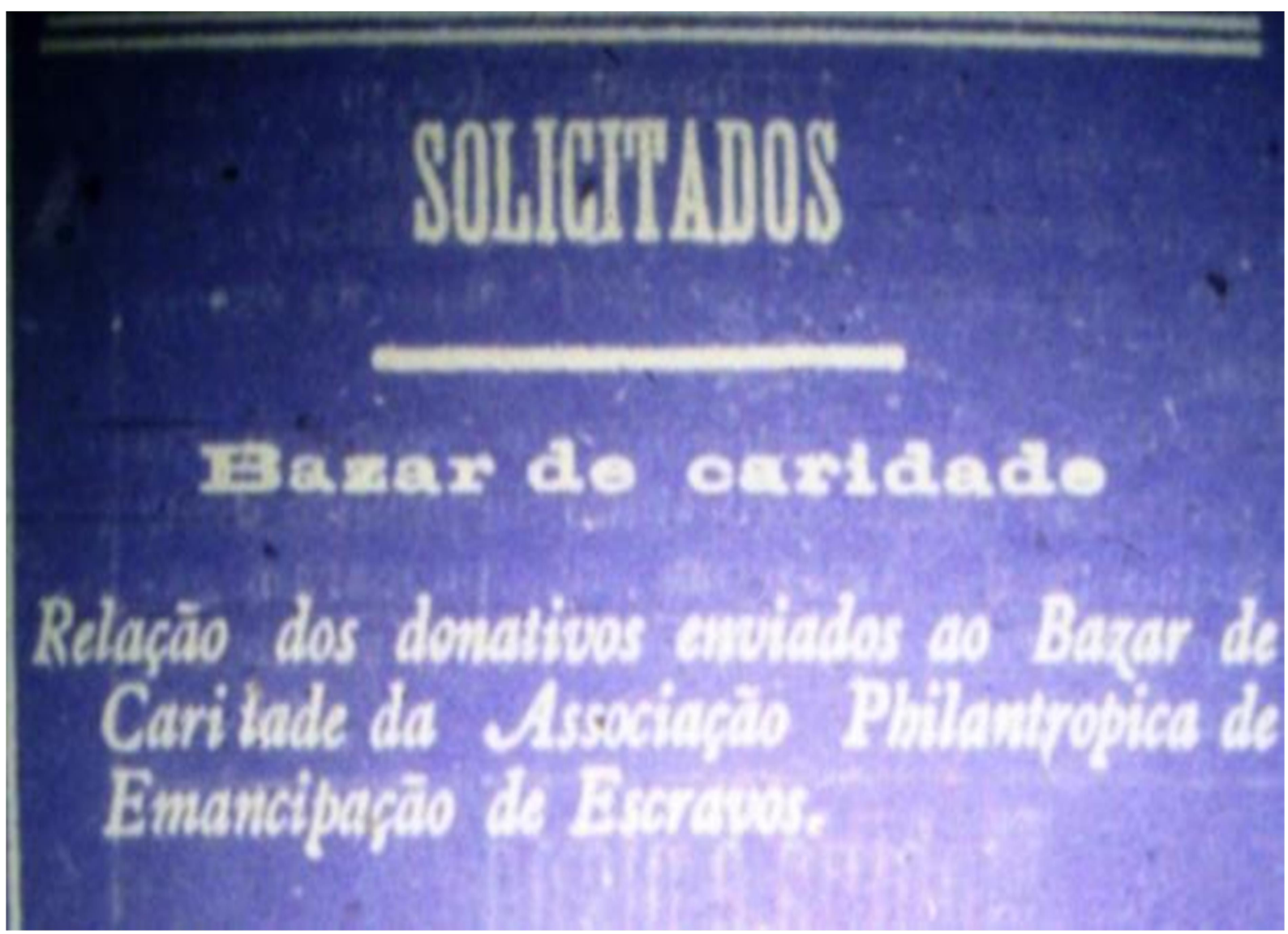

Foram pedidos doações em diversas localidades da província, cujos donativos chegavam pelos vapores que circulavam na província. Conforme ação dos "Srs. Martinho Guimarães e Visconde de Santo Elias, proprietários, aquele do vapor 'S. Miguel' e este do 'Elias' ofereceram transporte gratuito para todos os objectos destinados ao bazar de caridade e que sejam remetidos das localidades"

Entre os itens doados para sua realização encontramos o sentido dessa festa de caridade. Muitos desses donativos doados ou produzidos donativos faziam referências a temas fraternos ou correlatos ao objetivo do bazar, tais como a doação da "Sra. Maria Amalia R. de Abreo Maciel - uma carteira bordada á missangas com a palavra- Amôr." ${ }^{16}$ A oferta da senhora Amelia Lima de Carvalho Braga foi uma "primorosa bolsa para tabaco com palavra "Liberté",17 As noivas libertas, Maria José e Libania, doaram "dois bouquets, um com a palavra 'liberdade' e outro registrado 'amor'.,"18

\footnotetext{
${ }^{14}$ A A Província do Pará (10 de agosto de 1882, p.2).

${ }^{15}$ A Província do Pará (13 de junho de 1882, p. 3).

${ }^{16}$ A Província do Pará (23 de julho de 1882, p. 3).

${ }^{17}$ A Província do Pará (10 de julho de 1882, p. 3).

${ }^{18}$ A Província do Pará (14 de julho de 1882, p. 3).
} 
O período de angariação de objetos proporcionou "Uma variadíssima colecção de objectos de apreço [...] e o primeiro leilão já effectuado afirmou mais uma vez a generosidade do digno concurso de pessoas que affluiram"19. Por conseguinte, era destacado que os sentimentos de generosidade e sentimento de amor ao próximo, comemoração na qual, “Animem as famílias também com seu concurso a festa da caridade (Grifo nosso), que farão assim, mais jus as bênçãos dos que tiverem de gozar dentro em pouco da liberdade de que hoje se veem tolhidos"20.

Outra forma de angariar fundos para festa de liberdade eram as "caixas libertadoras". A subscrição social era marcada por ações que apelavam aos sentimentos de humanidade, amor ao próximo, especificamente à questão da liberdade. Nesse sentido que Jose Henrique Cordeiro de Castro, membro da Associação Philantrópica de Emancipação de Escravos, realizava pedido formal à municipalidade para "fazer colocar no mercado público, nas ruas e praças da capital, caixas com a denominação de libertadoras (Grifo nosso), com o fim de aumentar o fundo libertador",21.

Em 1887, a união de Raymundo José de Lima e Maria José de Lima, ocorrida na Igreja de Santo Alexandre, foi pretexto e motivação para que, novamente, perante os convidados e os familiares dos noivos "No acto do casamento foi entregue uma cartas de liberdade ao escravo Avelino, dada sem onus algum pela exm ${ }^{\mathrm{a}} \mathrm{sr}^{\mathrm{a}}$ Angela Lima, mãe da noiva. Desejamos uma verdadeira messe de felicidade ao jovem casal." 22

Ao aliar a ideia de "boa ação" ou ato de altruísmo que o periódico Diário de Belém informava liberdade de duas escravas, que foram libertadas "sem onus algum". A nota destacava que:

O Sr. Capitão Cezario de Santa Brigida Botelho e sua exma. Esposa d. Maria do Socorro Seabra Botelho, para darem maior realce ao acto de baptismo de seu estremecido neto, que teve lugar no dia 28 do mez findo, na capela da casa de sua residencia, no rio Maguary, concederão liberdade ás suas escravas Marianna e Felicia, sem onnus algum. Actos destes manifestão os bem formados corações de quem os pratica, e não precisam de commentarios para realçal-os. ${ }^{23}$

Nos anos finais da escravidão notas cujo fim eram anunciar ações de filantropia ou "caridade" se tornou mais comum e associavam comemorações em diferentes sentidos, tal qual o ritual cristão do batismo, cujo regozijo aliava a festividade cristã e o propósito de libertação.

\footnotetext{
${ }^{19}$ A Província do Pará. (22 de julho de 1882, p. 3).

${ }^{20}$ Idem.

${ }^{21}$ O Liberal do Pará (20 de agosto de 1882, p.1).

${ }^{22}$ Diário de Noticias. Casamento. 22 de outubro de 1887, p. 2

${ }^{23}$ Diário de Belém. Philantropia. 2 de julho de 1885 , p. 2 .
} 
O discurso empregado era de "benemerência" em prol da humanidade que antecipava ou antevia uma ação governamental ou mesmo dos clubes e associações emancipadores ou abolicionistas, mas principalmente um ato de rebeldia como abandono do trabalho ou fugas aos quilombos bastante acentuado nos anos finais da escravidão. Em meio às frentes do bazar foram organizadas festas artísticas, entrelaçadas como "festas de liberdade". Estas giraram em torno de apresentações artísticas, músicas e doação de recursos para o fundo de emancipação dos clubes e associações emancipacionistas ou abolicionistas.

Outra ocasião para amealhar fundos era por meio de festa artística, tal como ocorreu no Teatro da Paz em favor da atriz que "tem merecido geral aceitação os 247 bilhetes da plateia geral, remetida em favor do fundo de emancipação (...) pela gentil beneficiada Amina Orlandi. [...] Tendo alguns cavalheiros aceitados 20 a mais para distribuírem por dedicados abolicionistas" ${ }^{24}$. Ainda em 18882, em ação assemelhada o Club Abolicionista Patroni também lançou um "Bazar da Caridade" e associou tal ação à empresa artística Emília Adelaide em conjunto com a companhia dramática de Ribeiro Guimarães e anunciavam no Teatro da paz “Grande festa art'istica em favor da LIBERDADE esplendido espetaculo em beneficio do Club Abolicionistas Patroni”25 (Figura 2).

\footnotetext{
${ }^{24}$ O Liberal do Pará (22 de setembro de 1882, p.2)

${ }^{25}$ A Província do Pará (16 de junho de 1882, p. 3).
} 
Figura 2: Teatro da Paz: Cabana do Pai Tomás. ${ }^{26}$

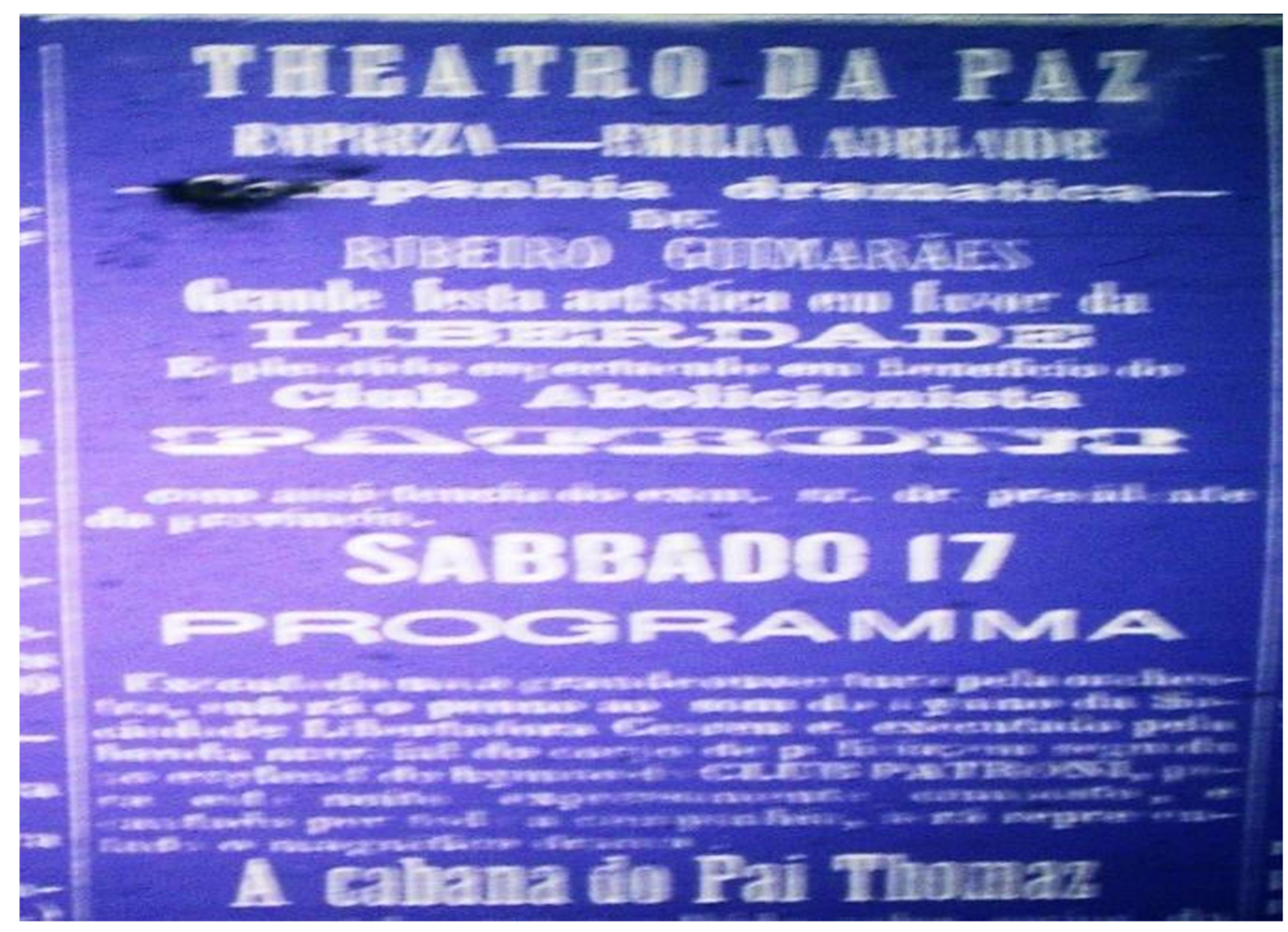

\section{LIBERTAVA-SE O "BOM CATIVO"}

Os recursos advindos das ações de caridade, tal quais provenientes do bazar ou festas artísticas, eram empregados em ações de liberdade. Porém, essas alforrias não eram aleatórias. Para que essas pessoas fossem agraciadas era necessário passar pelo filtro senhorial, instrumento típico das relações paternalistas do sistema escravagista.

As celebrações possibilitavam a exposição de posicionamento político, a construção de uma identidade coletiva e de legitimação social, o momento de mostra-se como "partidário da liberdade". Seja a lembrança do aniversário, o nascimento de um filho ou seu batizado, cerimônia em memoria de um ente querido, até a passagem de ano, tornavam-se momentos de "concessão" onerosa ou "gratuita" de cartas de liberdade.

Havia a idealização do escravizado enquanto critério para classificação dos outorgados com as alforrias. Como percebeu Bezerra Neto, o processo de escolha do sujeito apresentava um imaginário social girava em torno, por exemplo, de questões de cunho comportamental, 
valores "morais" e da avaliação dos senhores, influenciados pelas teorias racialistas, incidindo num filtro racial. ${ }^{27}$

A concessão de carta de liberdade era enfatizada questões morais, a liberdade ao bom trabalhador, indivíduos que valorizavam a família ou até mesmo "questões sentimentais". Havia, por exemplo, a concessão por conta dos "bons serviços prestados"28. Foi o caso da festa de liberdade que marcou a entrega da alforria do escravizado Fellipe, ocorrida em 1881, que foi realizada em meio ao regozijo das comemorações do decenário da lei do Ventre Livre, em 28 de setembro de 1881.

Durante a cerimônia ocorreram algumas considerações sobre o libertando Fellipe, ressaltando que "casando-se ás 5 horas da tarde no mesmo dia com Genoveva Maria dos Santos e reconhecida uma filha de nome Raymunda. Esta nova família, que acabava de assentar-se no grande baquete da comunhão social"29.

Além da festa, poderia ocorrer um gesto pessoal representativo de ação "filantrópica", de bondade, generosidade ou "boa fé", típico do paternalismo senhorial. Por exemplo, a concessão de carta do senhor José Antonio Rezende ocorreu por conta de que "enfermo e seguia para Europa no vapor inglez Sobralense, em busca da melhoria de sua saúde" ${ }^{\text {"30 A }}$ condição da alforria ocorreu por conta de que "dotado de sentimentos verdadeiramente abolicionista, acaba de conceder a liberdade a um seu escravo de nome Maximino, 21 anos de idade, e que segue em sua companhia" 31.

$\mathrm{Na}$ festa em comemoração ao casamento de Ricardo José de Oliveira Santo e Thereza Oliveira dos Santos ocorreram brindes e vivas ofertadas pelo senhor João Santos, pai da noiva "declarando que em homenagem a si e como demonstração de seu justo jubilo, declara livre, e pedia ao Sr. major Costa que entregasse carta de liberdade ao seu escravo Belmiro, de cor branca (Grifo nosso)"32.

Ao aliar a ideia de "boa ação" ou ato de altruísmo que o periódico Diário de Belém informava liberdade de duas escravas, que foram libertadas "sem onus algum". A nota destacava que:

\footnotetext{
${ }^{27}$ NETO (2015, p. 257-276).

${ }^{28}$ O Liberal do Pará (14 de abril de 1883, p.1). "Em 1883, durante cerimônia em memória pelo falecimento de José da Gama Malcher, chefe do partido liberal, na província do Pará, sua viúva e filhos "entrega hoje, por occasião da missa em que mandam rezar no cemitério Santa Izabel (...) quatro cartas de liberdade a escravos do casal, que por seus bons serviços prestados, se fizeram dignos de recompensa (GRIFO NOSSO)"

${ }^{29}$ A Constituição (28 de setembro de 1871, p. 1).

${ }^{30}$ Diário de Notícias (23 de abril de 1886, p.2).

${ }^{31} \mathrm{Idem}$.

${ }^{32}$ Diário de Noticias (22 de fevereiro de 1887, p. 2).
} 
O Sr. Capitão Cezario de Santa Brigida Botelho e sua exma. Esposa d. Maria do Socorro Seabra Botelho, para darem maior realce ao acto de baptismo de seu estremecido neto, que teve lugar no dia 28 do mez findo, na capela da casa de sua residencia, no rio Maguary, concederão liberdade ás suas escravas Marianna e Felicia, sem onnus algum. Actos destes manifestão os bem formados corações de quem os pratica, e não precisam de commentarios para realçal-os (DIÁRIO DE BELÉM, 1885, p.2).

Nos anos finais da escravidão notas cujo fim era a filantropia ou uma "caridade" que aliavam rituais de comemorações, tal qual o ritual cristão do batismo, e com fins libertação tornaram-se mais comuns.

Como analisa Bezerra Neto, durante a década do abolicionismo a referência um componente racial era representado nos critérios de escolha ou mesmo um imaginário social em que havia a projeção de um "liberto ideal",33 o compunha um imaginário social senhorial.

\section{CONSIDERAÇÕES FINAIS}

As festas de caridade ensejavam na memória social a representação do negro enquanto sujeito "inertes" a partir da visão senhorial, da elite letrada e dos diversos sujeitos entrelaçados, que idealizavam na representação benevolente de ação caridosa de "regeneração social" do liberador e do libertado. Essas festividades demarcavam a passagem simbólica da escravidão à liberdade, ação festiva de júbilo, congraçamento, ato caridoso.

Eram estratégias de um movimento sem traumas ou revanchismos, ou seja, afastavam as lutas e resistências cotidianas dos escravizados e buscavam consagrar a natureza pacífica e ordeira do abolicionismo ${ }^{34}$, conforme percebeu Bezerra Neto.

Nelas, havia a representação idealizada do negro, ora como sujeito pacífico e apto ao mundo da liberdade, outrora aquele que "esperava" uma ação graciosa e figurante no processo de libertação. Foi nessa compreensão que o literato paraense Marques de Carvalho compreendia o "papel” do negro nos festejos, na dimensão que:

Era o dia 13 de maio de 1888. As ruas do Pará tinham festiva aparência. Transbordando o povo rejubilado pelo conhecimento da lei que extinguira a escravidão no Brasil. Cruzavam-se no ar o enfusiamento de grandes girândolas de foguetes e o eco ingente de milhares de vozes bramindo entusiasmados louvores e vivas em honra ao glorioso sucesso. Galhardetes e coretos erguiam-se pelas ruas. Bandas marciais difundiam no espaço alegres harmonias de cálidos hinos excitantes. Da casa do Comendador Pereira de Castro correram para a rua todos os pretos a fim de lhes ser dada a parte a que tinham direito no geral regozijo [Grifo nosso] ${ }^{35}$.

\footnotetext{
${ }^{33}$ NETO (2009, p. 250).

${ }^{34}$ BEZERRA NETO, Op. Cit., p. 375.

${ }^{35}$ CARVALHO (2012, p.89).
} 
Essas premissas reveladas no fragmento do texto citado anteriormente, devemos considerar o formato das festas do abolicionismo buscava direcionar qual seria o "lugar dos negros". Representado como figurante e obediente são implicitamente ressaltados.

Podemos considerar que essas ações escravagistas partiam do pressuposto de que os libertados ainda restavam alguma "obediência" em relação aos seus senhores, como se fosse um ato de afirmação da sua condição de mandatários, proprietários contagiados pelo "espírito" de benevolência, bondade, representado seu ato como generoso, de humanidade, a festa de caridade.

Para Maria Helena Machado, a década do abolicionismo foi marcada pelo controle social sobre os trabalhadores, apagando o passado de exploração e violência em nome da construção de uma sociedade fraterna, de um congraçamento entre irmãos, a liberdade como “concessão".

Assim, as festas do abolicionismo, enquanto obra de "beneficência" pautada pela alegria e entusiasmo, ação caridosa e de amor à humanidade, conforme identifica Vicente Salles, poderiam tornar-se, ao mesmo tempo "um bom negócio" ${ }^{36}$ que incluía auferimento de valores pelas libertações e a continuação da exploração mediante a formalização de alforrias condicionais, com a prestação de serviço por até dois anos ${ }^{37}$.

As representações dos negros nos festejos do abolicionismo permitem pensarmos, por outro lado, como a memória social desse movimento pautou suas ações como "civilizadoras" ou mesmo progressistas, acabara inviabilizando a cultura negra, como percebeu Bezerra Neto.

Como identificou Renata Figueiredo de Moraes, o caráter polissêmico das festas de liberdade permite identificar "festas indesejadas" 38 cuja representação era pautada por batuques, danças, extrato da cultural específico e, de certa medida, malquistas.

Em 1885, o Diário de Notícias destacava uma nota segundo o qual "[...] o ativo e enérgico subdelegado do 4 distrito, Sr. lobo de Castro, avisado que continuava o imoral batuque [Grifo nosso] na travessia do Gloria(..)" ${ }^{39}$ As representações nos periódicos eram no sentido de mostrar que "de dia para dia cresce o número d'aqueles vagabundos [Grifo nosso].

\footnotetext{
${ }^{36}$ SALLES, Vicente. Op. Cit. p. 150

${ }^{37}$ Foi o caso do senhor de escravo Francisco Alves Teixeira que "[...] dando vivas aos abolicionistas, á imprensa, aos clubs abolicionistas, ao sr presidente da provincia, á todos que vierem honrar e á S. M. o Imperador, declarou que em seu dito engenho jamais haveria um trabalhador escravo; que actualmente os que ahi existem, em numero de 80, são todos livres. CF: Diário de Notícias. Abolicionismo. 20 de maio de 1884, p.2.

${ }^{38}$ MORAES (2011, pp. 315-334).

${ }^{39}$ Diário de notícia (O Batuque, 17 de setembro de 1885, p.3).
} 
[...] que o Sr. Dr. Chefe de polícia, por intermédio de seus agentes, procurasse dizimar essa quadrilha; ao contrário terá que lamentar factos graves." 40

A presença de capoeiras, por exemplo, demonstrava como em algumas ocasiões os negros tinham suas representações estereotipadas. Em 1884, um grupo de capoeiras foi denunciado, pois “[...] á noute, por occazião da passagem de musica da polícia na rua Formosa, os capoeiras, que em número superior á dez acompanhavam a mesma." 41 A nota destacava que capoeiras desafiavam as autoridades e que durante o tocar da banda de música, que geralmente em frente ao quartel de policia, não só importunavam como também “[...] espancaram dois indivíduos que procuravam a casa de seus correspondente, no qual conseguiram refugiar-se, perdendo um d'elles o chapéo e chinellas, que os capoeiras levaram." 42

As práticas culturais como batuques e sambas, a capoeiragem que cotidianamente se desenvolviam nas relações sociais era atrelada às representações e práticas culturais negativadas. Podemos observar essa questão, por exemplo:

\footnotetext{
Mora numa casa velha à travessa d'Atalaya um preto creoulo, de nome Lucio, dado ao officio de puçangueiro, de maneira que diariamente reúne em sua casa mulheres perdidas e desbocadas, que ali vão procurar fortuna e de noite faz procissões com a imagem de N. S., cantando ladainhas e dançando o samba incommodo da visinhança.

(...) houve uma d'essas procissões por haver se realizado uma cura, seguindo-se ladainha e batuque com muita cachaça e indecencia, até as ultimas horas da noite (DIÁRIO DE NOTÍCIAS, 1885, p. 3).
}

Dessa forma, revela que distante dos festejos do abolicionismo as representações giravam no eixo da desordem que incomodava "vizinhança" e as autoridades. Assim, a representação do negro nos festejos do abolicionismo primava por um filtro ideal, no qual os sujeitos eram caracterizados na ótica senhorial como apegados ao trabalho, prestativos e de boa índole, passivos figurantes no processo de liberdade. Ao escapar desse filtro, a sua representação era desqualificada ou mesmo indesejada, caracterizada como ação geradora de tensão social.

Apesar do discurso das festas enquanto ação de benevolência, muitos dos libertados durantes os festejos possuíam pecúlios depositados na tesouraria provincial, um predicado que atendia o critério do bom trabalhador, que poupava e apresentava um ofício, conforme os

\footnotetext{
${ }^{40}$ Idem.

${ }^{41}$ Diário de Notícias (Os capoeiras, 4 de junho de 1887, p. 2.)

${ }^{42}$ Idem.
} 
critérios $^{43}$ adotados por sociedades emancipadoras e abolicionistas e pelos próprios senhores que, porém, os alforriavam por "benevolência" nos momentos festivos.

Segundo Angela Alonso (2014), o abolicionismo deve ser compreendido como arena de embates e cenário de diversos atores políticos em movimento, marcado pela heterogeneidade social, em que permeou diversas visões de liberdades, que permitem pensar no processo de abolição e pós-abolição enquanto campo de luta políticas.

Nesse sentido, as reflexões desse artigo destacaram as festas na perspectiva de uma disputa em torno de uma memória social do abolicionismo, representação idealizada do negro como sujeito social integrante de um movimento que buscava legitimidade, adesões e fluidez social em meio ao caráter benevolente e harmônico do processo de liberdade.

\section{FONTES}

A Província do Pará (1882)

Diário de Notícias (1881-1887)

Diário de Belém (1887)

O Liberal do Pará (1882-1883)

\section{REFERÊNCIAS}

ALONSO, Angela. O abolicionismo como movimento social. Novos estud. CEBRAP [online]. $\quad 2014, \quad$ n.100, pp.115-127. $\quad$ ISSN 01013300. http://dx.doi.org/10.1590/S0101-33002014000300007. Acessado em 27 de junho de 2019.

ALONSO, Angela. Flores, Votos e Balas: o movimento abolicionista brasileiro (18681888). São Paulo: Cia das letras, $1^{\mathrm{a}}$ edição. 2015.

BEZERRA NETO, José Maia. Se bom cativo, liberto melhor ainda: Senhores, escravos e visões emancipadoras (1850-1888). In: Tornando-se livre: Agentes históricos e lutas sociais no processo de abolição. Organização, Maria Helena Pereira de Toledo Machado e Celso Thomas Castilho. São Paulo, editora da Universidade de São Paulo, 2015.

BEZERRA NETO, José Maia. A Segunda Independência. Emancipadores, Abolicionistas e as Emancipações no Brasil. Almanack. Guarulhos. N 2. PP. 87-100. $2^{\circ}$ semestre de 2011.

BEZERRA NETO, José Maia. Por Todos os Meios Legítimos e Legais: As Lutas contra a Escravidão e os Limites da Abolição (Brasil, Grão-Pará: 1850-1888). Tese (Doutorado em História) - Pontifícia Universidade Católica de São Paulo, Programa de Estudos PósGraduados em História, São Paulo, 2009.

\footnotetext{
${ }^{43}$ BEZERRA NETO, Op. Cit. P. 269-270.
} 
BEZERRA NETO, José Maia. $O$ doce treze de Maio. $O$ abolicionismo e as visões da Cabanagem, Grão-Pará-Século XIX. In: Neves, Fernando Arthur Freitas; Lima, Maria Roseane Pinto (Orgs.). Faces da história da Amazônia. Belém: Paka-tatu, 2006, pp. 341382.

BRASIL. Congresso. Senado. Leis. Lei no 2040 de 28 de setembro de 1871.

CARVALHO, João Marques de. Contos paraenses/ organização de Silvio Augusto de Oliveira e Elissandro Lopes de Araújo. Belém: Estudos amazônicos, 2012, p.89.

CHARTIER, Roger. A história Cultural: entre práticas e representações. Lisboa: Difel, s/d, p. 17.

COLEÇÃO DE LEIS DA PROVÍNCIA. Atos do Governo provincial do Grão-Pará. (18801888).

COSTA, Magda Nazaré Pereira da. Caridade e Saúde Pública em tempo de epidemias. Belém 1850-1890. Dissertação (Mestrado) - Centro de Filosofia e Ciências Humanas. Universidade Federal do Pará. Programa de Pós-graduação em História Social da Amazônia, Belém, 2006.

Diário de Belém. Philantropia. 2 de julho de 1885, p.2.

Diário de Notícias, 11 de dezembro de 1885, p.3.

DRESCHER, Seymourd. Abolição: uma história da escravidão e do antiescravismo. Tradução: Antonio Penalves Rocha. São Paulo: Editora da UNESP, 2011. 736p.

HALL. Stuart. Cultura e Representação. Editora da PUC: Rio de janeiro, 2016. Tradução: William Oliveira e Daniel Miranda. 264 p.

MACHADO, Maria Helena Pereira Toledo. O Plano e o Pânico: Os Movimentos Sociais na Década da Abolição. $2^{a}$ ed. rev. - São Paulo: Editora da Universidade de São Paulo, 2010. p.150.

MACHADO, Maria Helena Pereira Toledo; CASTILHO, Celso Thomas. In: Tornando-se livre: Agentes históricos e lutas sociais no processo de abolição. Organização, Maria Helena Pereira de Toledo Machado e Celso Thomas Castilho. São Paulo, editora da Universidade de São Paulo, 2015.

SALLES, Vicente. O Negro no Pará sob o regime da escravidão. $3^{\text {a }}$ edição revisada e ampl. Belém: IAP, programa Raízes, 2005. 